Elisa L. Hill, Thierry Gallopin, Isabelle Férézou, Bruno Cauli, Jean Rossier, Paul Schweitzer and Bertrand Lambolez

J Neurophysiol 97:2580-2589, 2007. First published Jan 31, 2007; doi:10.1152/jn.00603.2006

You might find this additional information useful...

This article cites 63 articles, 36 of which you can access free at:

http://jn.physiology.org/cgi/content/full/97/4/2580\#BIBL

Updated information and services including high-resolution figures, can be found at:

http://jn.physiology.org/cgi/content/full/97/4/2580

Additional material and information about Journal of Neurophysiology can be found at: http://www.the-aps.org/publications/jn

This information is current as of September 4, 2007. 


\title{
Functional CB1 Receptors Are Broadly Expressed in Neocortical GABAergic and Glutamatergic Neurons
}

\author{
Elisa L. Hill, ${ }^{1}$ Thierry Gallopin, ${ }^{1}$ Isabelle Férézou, ${ }^{1}$ Bruno Cauli, ${ }^{1}$ Jean Rossier, ${ }^{1}$ Paul Schweitzer, ${ }^{2}$ and \\ Bertrand Lambolez ${ }^{1}$ \\ ${ }^{1}$ Laboratoire de Neurobiologie et Diversité Cellulaire, Centre National de la Recherche Scientifique Unité Mixte de Recherche 7637, Ecole \\ Supérieure de Physique et de Chimie Industrielles, Paris, France; and ${ }^{2}$ Molecular and Integrative Neurosciences Department, The Scripps \\ Research Institute, La Jolla, California
}

Submitted 9 June 2006; accepted in final form 31 January 2007

\begin{abstract}
Hill EL, Gallopin T, Férézou I, Cauli B, Rossier J, Schweitzer P, Lambolez B. Functional CB1 receptors are broadly expressed in neocortical GABAergic and glutamatergic neurons. J Neurophysiol 97: 2580-2589, 2007. First published January 31, 2007; doi:10.1152/jn.00603.2006. The cannabinoid receptor $\mathrm{CB} 1$ is found in abundance in brain neurons, whereas $\mathrm{CB} 2$ is essentially expressed outside the brain. In the neocortex, CB1 is observed predominantly on large cholecystokinin (CCK)-expressing interneurons. However, physiological evidence suggests that functional $\mathrm{CB} 1$ are present on other neocortical neuronal types. We investigated the expression of CB1 and CB2 in identified neurons of rat neocortical slices using single-cell RT-PCR. We found that $63 \%$ of somatostatin (SST)-expressing and $69 \%$ of vasoactive intestinal polypeptide (VIP)-expressing interneurons co-expressed CB1. As much as $49 \%$ of pyramidal neurons expressed CB1. In contrast, CB2 was observed in a small proportion of neocortical neurons. We performed whole cell recordings of pyramidal neurons to corroborate our molecular findings. Inhibitory postsynaptic currents (IPSCs) induced by a mixed muscarinic/nicotinic cholinergic agonist showed depolarization-induced suppression of inhibition and were decreased by the CB1 agonist WIN-55212-2 (WIN-2), suggesting that interneurons excited by cholinergic agonists (mainly SST and VIP neurons) possess CB1. IPSCs elicited by a nicotinic receptor agonist were also reduced in the presence of WIN-2, suggesting that neurons excited by nicotinic agonists (mainly VIP neurons) indeed possess CB1. WIN-2 largely decreased excitatory postsynaptic currents evoked by intracortical electrical stimulation, pointing at the presence of CB1 on glutamatergic pyramidal neurons. All WIN-2 effects were strongly reduced by the CB1 antagonist AM 251. We conclude that $\mathrm{CB} 1$ is expressed in various neocortical neuronal populations, including glutamatergic neurons. Our combined molecular and physiological data suggest that $\mathrm{CB} 1$ widely mediates endocannabinoid effects on glutamatergic and GABAergic transmission to modulate cortical networks.
\end{abstract}

I N T R O D U C T I O N

Cannabinoid substances act at $\mathrm{CB} 1$ receptors to impair brain functioning in a variety of cognitive and performance tasks, including memory, learning, and attention (Iversen 2003); and endogenous ligands for these receptors, the endocannabinoids, have emerged as transmitters regulating neuronal activity (Freund et al. 2003). CB1 is found throughout the brain and is present at a high density in neocortex and hippocampus (Herkenham et al. 1990). In these brain areas, CB1 immunoreactivity is mostly found on large cholecystokinin (CCK)expressing interneurons but not vasoactive intestinal peptide

Address for reprint requests and other correspondence: B. Lambolez, NPA, CNRS UMR 7102, UPMC, 9 quai St Bernard 75005 Paris, France (E-mail: bertrand.lambolez@snv.jussieu.fr).
(VIP)- or somatostatin (SST)-expressing interneurons (Bodor et al. 2005; Katona et al. 1999; Tsou et al. 1999). The CB1 mRNA is expressed in pyramidal neurons (Marsicano and Lutz 1999; Matsuda et al. 1993), but CB1 immunoreactivity has often been undetected in these neurons (Bodor et al. 2005; Katona et al. 1999; Tsou et al. 1999). Although the presence of CB1 immunoreactivity at hippocampal excitatory presynaptic terminals has been recently reported (Katona et al. 2006; Kawamura et al. 2006), the extent of cortical CB1 expression in pyramidal neurons remains unclear.

Numerous electrophysiological studies have investigated the influence of cannabinoids in brain preparations. In neocortex and hippocampus, cannabinoids acting at CB1 depress inhibitory and excitatory synaptic transmission (Auclair et al. 2000; Bender et al. 2006; Davies et al. 2002; Fortin and Levine 2006; Piomelli 2003; Sjostrom et al. 2003, 2004). The use of CB1 knock-out mice further established the occurrence of functional CB1 on forebrain glutamatergic neurons (Domenici et al. 2006; Kawamura et al. 2006; Marsicano et al. 2003; Takahashi and Castillo 2006). Yet the CB1 expression patterns in glutamatergic neurons remain unclear, and this prompted us to investigate the expression of CB1 in pyramidal neurons of the neocortex.

Endocannabinoids act as retrograde messengers to elicit the phenomenon of depolarization-induced suppression of inhibition (DSI) (Wilson and Nicoll 2001). DSI has been observed in neocortex (Bodor et al. 2005; Trettel and Levine 2002, 2003; Trettel et al. 2004), and activation of cholinergic receptors is often required to obtain significant DSI (Martin and Alger 1999), implicating acetylcholine-responsive interneurons expressing CB1 to contribute to DSI (Trettel et al. 2004). Neocortical interneurons expressing cholinergic receptors typically co-express SST or VIP (Gulledge et al. 2006; Kawaguchi 1997; Porter et al. 1999), suggesting that these interneuron populations also possess $\mathrm{CB} 1$ in contradiction with the reported presence of CB1 mainly on large CCK neurons. Therefore we investigated the expression of CB1 in SST and VIP interneuron populations.

Cannabinoids also act at CB2, which is principally found outside the brain, but mediates part of cannabinoid effects on cerebellar granule cells (Skaper et al. 1996) and brain stem neurons (Van Sickle et al. 2005). Although CB2 is only present at low level in the cortex (Van Sickle et al. 2005), we probed its expression in parallel with that of CB1.

\footnotetext{
The costs of publication of this article were defrayed in part by the payment of page charges. The article must therefore be hereby marked "advertisement" in accordance with 18 U.S.C. Section 1734 solely to indicate this fact.
} 
We used single-cell reverse transcription-polymerase chain reaction (scPCR) to investigate the expression of $\mathrm{CB} 1$ and $\mathrm{CB} 2$ in neocortical neurons. scPCR enabled us to characterize receptor expression in identified single neurons, eliminating the problem of nonspecific or background labeling levels. We also performed whole cell recordings of excitatory and inhibitory synaptic transmission to corroborate our molecular findings. Both our scPCR and electrophysiological data indicate that CB1, but not CB2, is widely expressed in SST and VIP interneurons as well as pyramidal neurons. Our findings suggest a broad role for the cannabinoid system of transmitters to modulate cortical networks.

\section{METHODS}

\section{Slice preparation}

Wistar rats (14-21 days old) were decapitated, and $300-\mu \mathrm{m}$-thick parasagittal sections of cerebral sensorimotor cortex were prepared as described previously (Cauli et al. 1997). The slices were incubated at room temperature $\left(22^{\circ} \mathrm{C}\right)$ in artificial cerebrospinal fluid (ACSF) containing (in mM) $126 \mathrm{NaCl}, 2.5 \mathrm{KCl}, 1.25 \mathrm{NaH}_{2} \mathrm{PO}_{4}, 2 \mathrm{CaCl}_{2}, 1$ $\mathrm{MgCl}_{2}, 26 \mathrm{NaHCO}_{3}, 20$ glucose, and 5 pyruvate, which was bubbled with a mixture of $95 \% \mathrm{O}_{2}-5 \% \mathrm{CO}_{2}$.

\section{Drugs}

All drugs and chemicals were obtained from Sigma (Saint Louis, MO) except tetrodotoxin (TTX), which was purchased from Latoxan (Valence, France). Drug concentrations were as follows: carbachol (CCh), $3 \mu \mathrm{M}$; 6-cyano-7-nitroquinoxalene-2,3-dione (CNQX), 10 $\mu \mathrm{M}$; D-AP5, $20 \mu \mathrm{M}$; WIN-55212-2 (WIN-2), $2 \mu \mathrm{M}$; AM 251, $2 \mu \mathrm{M}$; 1-1-dimethyl-4-phenyl-piperazinium iodide (DMPP), $100 \mu \mathrm{M}$; atropine, $5 \mu \mathrm{M}$; kynurenate, $1 \mathrm{mM}$.

\section{Whole cell recordings}

Slices were transferred to a recording chamber placed under a microscope (Axioscop FS Zeiss, Germany) and superfused at 2 $\mathrm{ml} / \mathrm{min}$ with ACSF at room temperature. Patch pipettes (5-7 M $\Omega$ ), pulled from borosilicate glass, were filled with $8 \mu \mathrm{l}$ internal solution. Membrane potentials were not corrected for junction potential. For characterization of neuronal types, investigation of electrophysiological properties and scPCR, we used an internal solution containing (in $\mathrm{mM}) 144 \mathrm{~K}$-gluconate, $3 \mathrm{MgCl}_{2}, 0.5 \mathrm{EGTA}$, and $10 \mathrm{HEPES}$ and 2 $\mathrm{mg} / \mathrm{ml}$ biocytin (Sigma). The $\mathrm{pH}$ was adjusted to 7.2 and osmolarity to $285 / 295$ mosM. Whole cell recordings were made from layers I to $\mathrm{V}$ neurons selected under infrared videomicroscopy (Stuart et al. 1993) with a patch-clamp amplifier (Axopatch 200A, Axon Instruments, Foster City, CA) connected to a Digidata 1200B interface board (Axon Instruments). Signals were amplified and collected using the data-acquisition software P-Clamp-8.02 (Axon Instruments). Recorded neurons were characterized by their firing properties as regular spiking pyramidal, fast spiking, regular spiking nonpyramidal, or irregular spiking cells as previously established (Cauli et al. 1997, 2000; Kawaguchi 1993, 1995; Kawaguchi and Kubota 1993). Fastspiking neurons, which are either insensitive or inhibited by cholinergic agonists (Gulledge et al. 2006; Kawaguchi 1997; Porter et al. 1999; Xiang et al. 1998), were discarded from the present study.

\section{GABAergic transmission}

Whole cell recordings were made from layers II/III or V pyramidal cells using an internal solution containing (in $\mathrm{mM}$ ) $144 \mathrm{CsCl}, 3$ $\mathrm{MgCl}_{2}, 10$ EGTA, 10 HEPES, and 5 QX-314 and $2 \mathrm{mg} / \mathrm{ml}$ biocytin. Neurons were voltage clamped and held at $-60 \mathrm{mV}$. To augment interneuron activity and subsequently increase GABA release onto pyramidal neurons, we preapplied $\mathrm{CCh}(3 \mu \mathrm{M})$ for $\geq 3 \mathrm{~min}$ and throughout the experiment. Inhibitory postsynaptic currents (IPSCs) were subsequently recorded in the presence of CNQX $(10 \mu \mathrm{M})$ and D-APV $(20 \mu \mathrm{M})$ to block glutamate transmission. IPSCs were analyzed using MiniAnalysis software (Synaptosoft, Decatur, GA) with a minimum threshold set at 7 pA. DSI was induced by a 2-s depolarization from -60 to $0 \mathrm{mV}$. For each neuron, DSI was attempted at least three times, and the mean DSI was calculated as the percentage of inhibition corresponding to the ratio between the average amplitude of IPSCs during the first $10 \mathrm{~s}$ after the induction protocol and the average amplitude $60 \mathrm{~s}$ before DSI. Following the DSI protocol, IPSCs were recorded for a 2 min period before applying WIN-2 (2 $\mu \mathrm{M})$ for a minimum of $5 \mathrm{~min}$. The maximum effect of WIN-2 was usually observed about 8 min after the beginning of WIN-2 application. IPSC amplitude and inter-event interval were measured during a 2- min period at the maximum WIN-2 effect and compared with control condition. WIN-2 effects on CCh-induced IPSCs was also investigated in the presence of $2 \mu \mathrm{M}$ AM 251, which was applied for 10 min before WIN-2 application. In another set of experiments, the nicotinic agonist DMPP $(100 \mu \mathrm{M})$ was applied for $10 \mathrm{~s}$ in the presence of CNQX $(10 \mu \mathrm{M})$, D-APV $(20 \mu \mathrm{M})$, and muscarinic receptor antagonist atropine $(5 \mu \mathrm{M})$. DMPP-induced IPSCs were recorded in pyramidal neurons in the presence and absence of WIN-2 $(2 \mu \mathrm{M})$. The same protocol was repeated in slices pretreated with 2 $\mu \mathrm{M}$ AM 251.

\section{Glutamatergic transmission}

We performed extracellular stimulation by using conventional glass electrodes (filled with ACSF) placed in layer II/III, $\sim 250 \mu \mathrm{m}$ rostral to the recorded layer II/III pyramidal neuron. Stimulation $(10-40 \mu \mathrm{A}$, $0.2-0.5 \mathrm{~ms}$ ) was delivered every $15 \mathrm{~s}$ using a stimulation isolation unit (Isolator-11, Axon Instruments). Whole cell recordings were made from layers II/III pyramidal cells using an internal solution

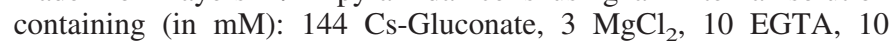
HEPES, and 5 QX-314 and $2 \mathrm{mg} / \mathrm{ml}$ biocytin $\left(E_{\mathrm{Cl}}=-78 \mathrm{mV}\right.$ in these experimental conditions). Neurons were voltage clamped and held at $-60 \mathrm{mV}$. We applied a hyperpolarizing voltage step $(5 \mathrm{mV})$ before each stimulation to monitor passive electrical properties of the recorded cell as well as access resistance, which did not vary $>20 \%$ during the analyzed recording period. Access resistance was not compensated. For each experiment, we applied $2 \mu \mathrm{M}$ WIN-2 for 15-25 min. For EPSCs analysis, the mean control amplitude (measured over a 2.5 -min period prior to WIN-2 application, $n=10$ stimulations) was compared with the mean EPSC amplitude recorded during the final 2.5 min of WIN-2 application. At the end of the experiment, we applied $1 \mathrm{mM}$ kynurenate $(5-10 \mathrm{~min})$ to confirm the glutamatergic nature of the EPSC. The same protocol was repeated in slices pretreated with $2 \mu \mathrm{M}$ AM 251 .

All values presented in this study are means \pm SE. Statistical analyses for these experiments were conducted using Statistica software (StatSoft, Tulsa, OK). Statistical significance was assessed with Student's paired $t$-test. $P$ value $<0.05$ was considered statistically significant.

\section{Single cell RT-PCR}

We performed cytoplasm harvesting of the recorded neurons and reverse transcription essentially as previously described (Lambolez et al. 1992). After recording, the cell's cytoplasm was aspirated into the recording pipette by application of a gentle negative pressure while maintaining the tight seal. Harvesting of the nucleus was carefully avoided. The pipette was then delicately removed to allow outside-out patch formation. Then the content of the pipette was expelled into a test tube and reverse transcription was performed in a final volume of $10 \mu \mathrm{l}$. We performed two steps of multiplex PCR as described (Cauli 
et al. 1997). The cDNAs present in the $10 \mu \mathrm{l}$ reverse transcription reaction were first amplified simultaneously using primer pairs described in Table 1 (sense and antisense primers were positioned on 2 different exons, except for CB1, CB2 and SST intron). We added taq polymerase (2.5 Units, Qiagen $\mathrm{GmbH}$, Hilden, Germany) and $20 \mathrm{pmol}$ of each primer to the buffer supplied by the manufacturer (final volume: $100 \mu \mathrm{l})$ and 20 cycles $\left(94^{\circ} \mathrm{C}, 30 \mathrm{~s} ; 60^{\circ} \mathrm{C}, 30 \mathrm{~s} ; 72^{\circ} \mathrm{C}, 35 \mathrm{~s}\right)$ of PCR were run. We then performed second rounds of PCR using $2 \mu \mathrm{l}$ of the first PCR product as template. In this second round, each cDNA was individually amplified using its specific primer pair by performing 35 PCR cycles (as described above). $10 \mu \mathrm{l}$ of each individual PCR reaction were then run on a $2 \%$ agarose gel using $\phi \times 174$ digested by HaeIII as molecular weight marker and stained with ethidium bromide.

\section{Identification of the PCR products and testing of the scPCR protocol}

We analyzed PCR-generated fragments obtained from each cell by fluorescence resonance energy transfer (FRET) between two adjacent oligoprobes (Table 1, purchased from Proligo, Paris, France) internal to the amplified sequence. The upstream probe was FITC-labeled at the $3^{\prime}$ end (donor, excitation $470 \mathrm{~nm}$ ) and the downstream probe Red705-labeled at the 5' end (acceptor, emission, $710 \mathrm{~nm}$ ). FRET between the two fluorophores, which can only occur when both probes are hybridized to their cognate PCR fragment, was measured with a LightCycler instrument (Roche Diagnostics GmbH, Mannheim, Germany) as described (Ferezou et al. 2002). The RT-PCR protocol was tested on $500 \mathrm{pg}$ of total RNA purified from rat neocortex. All of the cDNAs were detected from 500 pg of neocortical total RNA; whereas the SST gene intron was detected from $10 \mathrm{ng}$ of rat genomic DNA. The sizes of the PCR generated fragments were as predicted from published sequences (see Table 1) and their identity was confirmed by FRET between adjacent oligoprobes (as described in the preceding text).

\section{Cellular morphology}

We performed diaminobenzidine labeling of the recorded neurons filled with biocytin using the $\mathrm{ABC}$ elite kit (Vector Laboratories, Burlingame, CA). Images of neurons were captured using a Leica DMR light microscope (Leica Microsystems, Rueil-Malmaison, France) coupled with a Canon Powershot S45 digital camera (Canon France, Courbevoie, France).

\section{R E S U L T S}

\section{Expression of CB1 mRNA in cortical neurons}

We analyzed neocortical neurons by scPCR to investigate the expression of CB1 and CB2 mRNAs. The recorded neurons were characterized by their intrinsic firing patterns and mRNA expression profiles, and several neurons were randomly selected and assessed for morphology following biocytin labeling. In all neurons, we investigated the expression of the interneuronal markers: glutamic acid decarboxylase (GAD65 and GAD67), calbindin (CaB), calretinin (CR), neuropeptide $\mathrm{Y}$ (NPY), CCK, VIP, and SST, together with CB1 and CB2. In addition, for putative pyramidal cells we included the vesicular glutamate transporter vGLUT1 in the scPCR protocol to confirm their glutamatergic nature. Because CB1 and CB2 amplified sequences are intronless, a negative control for genomic DNA contamination (amplifying the SST gene intron) was always included to ascertain the mRNA origin of the CB1 amplified product (see METHODS). We tested genomic DNA contamination on 10 pyramidal neurons processed as described in METHODS except that reverse transcriptase was omitted. No PCR product was detected in this sample except in one cell positive for $\mathrm{CB} 1, \mathrm{CB} 2$, and the SST intron. This indicates that genomic DNA contamination occurred at a low frequency and was reliably detected by SST intron amplification. We discarded SST intron-positive cells from the present study $(2.8 \%$

TABLE 1. PCR primers and FRET probes

\begin{tabular}{|c|c|c|c|}
\hline & Size & PCR Primers & FRET Probes \\
\hline CB1 & \multirow[t]{2}{*}{351} & Sense, 42 : TACCATCACCACAGACCTCCTC & 3' FITC, 176: CAAGAAAAGATGACCGCAGGAGAC \\
\hline No. X55812 & & Antisense, 373 : GTGAAGGTGCCCAGTGTGAG & 5' R705, 200 : ACTCCCCGTTGGTCCCAGC \\
\hline CB2 & \multirow[t]{2}{*}{434} & Sense, 571 : CTCCTGGGCTGGCTTCTTTT & 3' FITC, 893 : TTTATGCCCTGCGGAGTGGA \\
\hline No. AF176350 & & Antisense, 983 : GACTTTGGGGCTTCTTCTTTCC & 5’ R705, 914 : AGATCCGCTCTGCTGCCCA \\
\hline vGlut1 & \multirow[t]{2}{*}{259} & Sense $^{\mathrm{d}}, 361$ : GGCTCCTTTTTCTGGGGGTAC & 3' FITC, 413 : GCCAAAAATTCGCAGCCAAC \\
\hline No. U07609 & & Antisense $^{\mathrm{d}}, 600$ : CCAGCCGACTCCGTTCTAAG & 5' R705, 434 : GGGTCTTTGGCTTTGCCATTG \\
\hline Gad65 & \multirow[t]{2}{*}{391} & Sense $^{\mathrm{a}}, 713:$ TCTTTTCTCCTGGTGGTGCC & $3^{\prime}$ FITC $^{c} 848$ : TTTCTCTCAAGAAGGGAGCTGCA \\
\hline No. M72422 & & Antisense $^{\mathrm{a}}, 1085$ : CCCCAAGCAGCATCCACAT & 5' R705' 872 : CCTTGGGGATCGGAACAGACA \\
\hline Gad67 & \multirow[t]{2}{*}{600} & Sense $^{\mathrm{b}}, 713$ : TACGGGGTTCGCACAGGTC & 3' FITC ${ }^{c} 930$ : CCTGGGGGAGCCATATCCAA \\
\hline No. M76177 & & Antisense, $1294:$ same as GAD65 & 5' R705 951 : ATGTACAGCATCATGGCGGCTC \\
\hline $\mathrm{CaB}$ & \multirow[t]{2}{*}{432} & Sense $^{\mathrm{b}}$, 134: AGGCACGAAAGAAGGCTGGAT & 3' FITC $^{\mathrm{c}} 263$ : TCCTGCTGCTCTTTCGATGCC \\
\hline No. M27839 & & Antisense $^{\mathrm{b}}, 544$ : TCCCACACATTTTGATTCCCTG & $5^{\prime} \mathrm{R}^{2} 5^{\mathrm{c}} 285$ : GCAACTGAAGTCCTGCGAGGAA \\
\hline $\mathrm{CR}$ & \multirow[t]{2}{*}{309} & Sense $^{\mathrm{b}}, 142$ : CTGGAGAAGGCAAGGAAAGGT & $3^{\prime}$ FITC $^{c} 248:$ TTGAGATGGCAGAGCTGGCG \\
\hline No. X66974 & & Antisense $^{\mathrm{b}}$, 429 : AGGTTCATCATAGGGACGGTTG & $5^{\prime} \mathrm{R}^{\prime} 05^{\mathrm{c}} 269$ : AGATCCTGCCAACCGAAGAGAAT \\
\hline NPY & \multirow[t]{2}{*}{359} & Sense $^{\mathrm{b}},-45:$ GCCCAGAGCAGAGCACCC & $3^{\prime}$ FITC $^{c} 17:$ AACGAATGGGGCTGTGTGGA \\
\hline No. M15880 & & Antisense $^{\mathrm{b}}$, 292 : CAAGTTTCATTTCCCATCACCA & $5^{\prime}$ R705 $38:$ TGACCCTCGCTCTATCCCTGC \\
\hline SST & \multirow[t]{2}{*}{209} & Sense $^{\mathrm{b}}, 43:$ ATCGTCCTGGCTTTGGGC & $3^{\prime}$ FITC $^{\mathrm{c}} 105$ : GCAGAAGTCTCTGGCGGCTG \\
\hline No. K02248 & & Antisense $^{\mathrm{b}}, 231$ : GCCTCATCTCGTCCTGCTCA & 5' R705' 126: CACCGGGAAACAGGAACTGGC \\
\hline VIP & \multirow[t]{2}{*}{286} & Sense $^{\mathrm{b}}, 167:$ TGCCTTAGCGGAGAATGACA & $3^{\prime}$ FITC $^{\mathrm{c}} 199$ : TGTGTCCAGAAATGCCAGGCA \\
\hline No. X02341 & & Antisense $^{\mathrm{b}}, 434$ : CCTCACTGCTCCTCTTCCCA & 5' R705 221 : GCTGATGGAGTTTTCACCAGCG \\
\hline $\mathrm{CCK}$ & \multirow[t]{2}{*}{216} & Sense $^{\mathrm{b}}, 174$ : CGCACTGCTAGCCCGATACA & $3^{\prime}$ FITC $^{c} 198$ : CCAGCAGGTCCGCAAAGCT \\
\hline No. K01259 & & Antisense $^{\mathrm{b}}, 373$ : TTTCTCATTCCGCCTCCTCC & 5' R705c, 218 : CCTCTGGCCGCATGTCCG \\
\hline SST Intron & \multirow[t]{3}{*}{421} & Sense, 143: GGAAATGGCTGGGACTCGTC & \multirow{2}{*}{ Not analyzed } \\
\hline \multirow[t]{2}{*}{ No. K02248 } & & Antisense, 540 : AAACCATGGATGATAGGAAGTCGT & \\
\hline & & & Position $1: 1^{\text {st }}$ base of the start coden \\
\hline
\end{tabular}

FRET, fluorescence resonance energy transfer. ${ }^{a}$ Bochet et al. 1994; ${ }^{b}$ Cauli et al. 1997; ${ }^{c}$ Ferezou et al. 2002 ; ${ }^{\mathrm{d}}$ Gallopin et al. 2006. 
of sampled cells). Last, we tested mRNA contamination from surrounding tissue by placing a patch pipette into the slice without establishing a seal. Positive pressure was then interrupted, and following removal of the pipette its content was processed as described. No PCR product was obtained using this protocol $(n=20)$.

We focused on three main cell populations throughout the present study. Two populations were SST- and VIP-containing interneurons comprising a total of 149 cells. These neurons were found to express GAD and displayed regular spiking nonpyramidal or irregular spiking patterns. Histological analysis of 11 SST- and 26 VIP-expressing neurons demonstrated bipolar/bitufted or multipolar dendritic morphology. These electrophysiological and morphological properties were consistent with those described in previous reports (Bayraktar et al. 2000; Cauli et al. 1997; Kawaguchi and Kubota 1996; Porter et al. 1998; Somogyi et al. 1984; Wang et al. 2004). The third population consisted of 106 pyramidal neurons $(n=39$ from layer II/III and $n=67$ from layer V) that showed typical low-frequency regular-spiking patterns, expressed mRNA for vGlut1, and were negative for GAD. Histological analysis of 55 pyramidal neurons revealed a clear apical dendrite. Representative examples of the three cell populations studied are depicted in Fig. 1.

A majority (63\%) of SST-expressing interneurons also expressed CB1 $(n=62$; Fig. $2 A)$. In contrast, CB2 was only found in $13 \%$ of SST-expressing interneurons. We also observed a high occurrence of $\mathrm{CaB}(48 \%)$ and a lower occurrence of CCK (32\%) and VIP (21\%) in SST interneurons, consistent with previous findings (Cauli et al. 2000; Gallopin et al. 2006; Gonchar and Burkhalter 1997; Kubota et al. 1994; Papadopoulos et al. 1987; Somogyi et al. 1984; Toledo-Rodriguez et al. 2005; Wang et al. 2004). Analysis of VIP-expressing interneurons revealed that $69 \%$ of these cells co-expressed CB1 but that only $4 \%$ co-expressed CB2 $(n=100$; Fig. $2 B)$. Consistent with previous findings (Cauli et al. 2000; Gallopin et al. 2006;
A
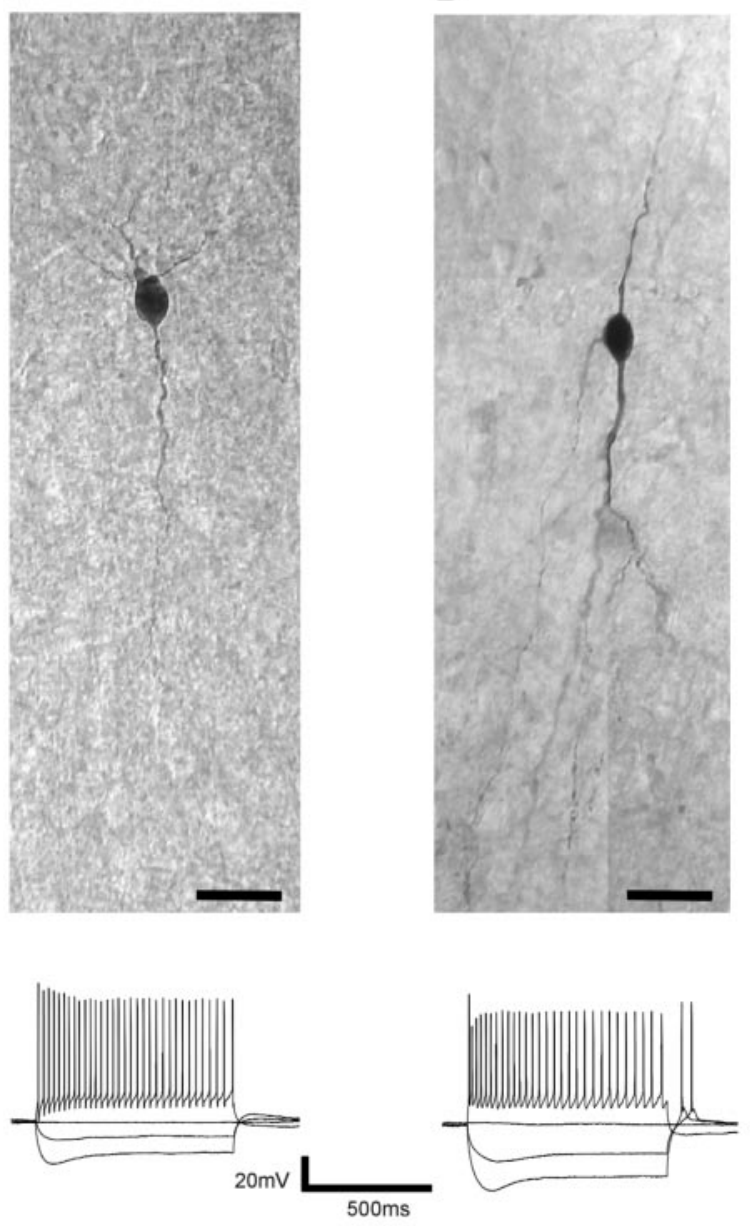

C
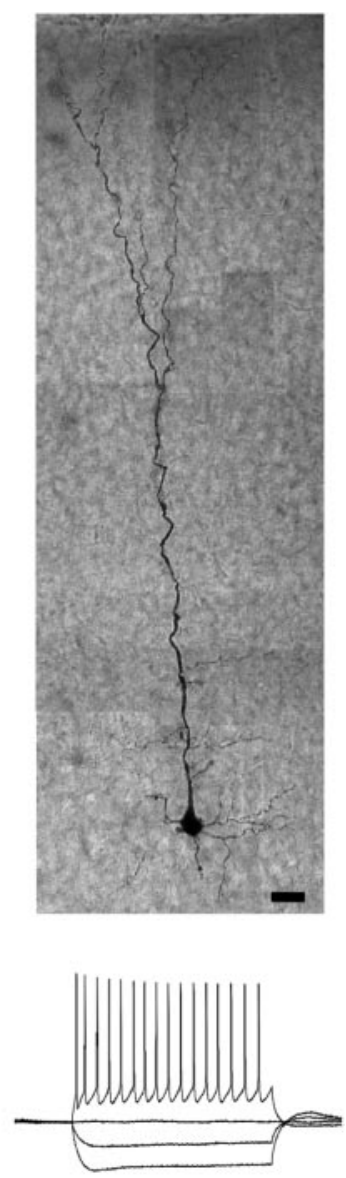

FIG. 1. Morphological, physiological, and molecular characterization of somatostatin (SST) interneurons, vasoactive intestinal polypeptide (VIP) interneurons and pyramidal cells. A, top: SST neurons showed a bitufted or multipolar morphology (note multiple dendrites emerging from the apical aspect of the soma). Pial surface is upward and scale bar is $20 \mu \mathrm{m}$ (same in $B$ and $C$ ). Middle: responses of the same neuron recorded in current-clamp mode (holding potential, $-60 \mathrm{mV}$ ) to hyperpolarizing and depolarizing current steps $(-100,-50$, and $+100 \mathrm{pA}$ ). This neuron exhibited a regular spiking firing pattern. The agarose gel analysis of single-cell reverse transcription-polymerase chain reaction (scPCR) products (bottom) showed that this neuron expressed glutamic acid decarboxylase 65 and 67 (GAD65 and GAD67), calbindin (CaB), SST, and CB1 mRNAs. Positions of the 603- and 310-bp bands of $\phi x 174 /$ HaeIII marker are indicated. $B$ : this biocytin-labeled neuron exhibited a bipolar morphology and a regular spiking discharge (middle) typical of VIP interneurons, and expressed GAD65 and 67, VIP, cholecystokinin (CCK), and CB1 mRNAs (bottom). C: pyramidal neurons demonstrated a prominent apical dendrite and basal lateral dendrites. This cell exhibited a typical slow regular firing pattern (middle) and expressed vGlut1 together with CB1 (bottom).
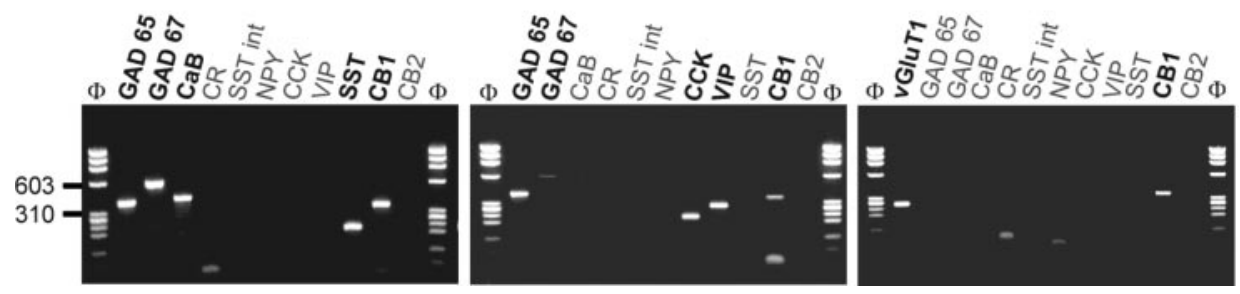

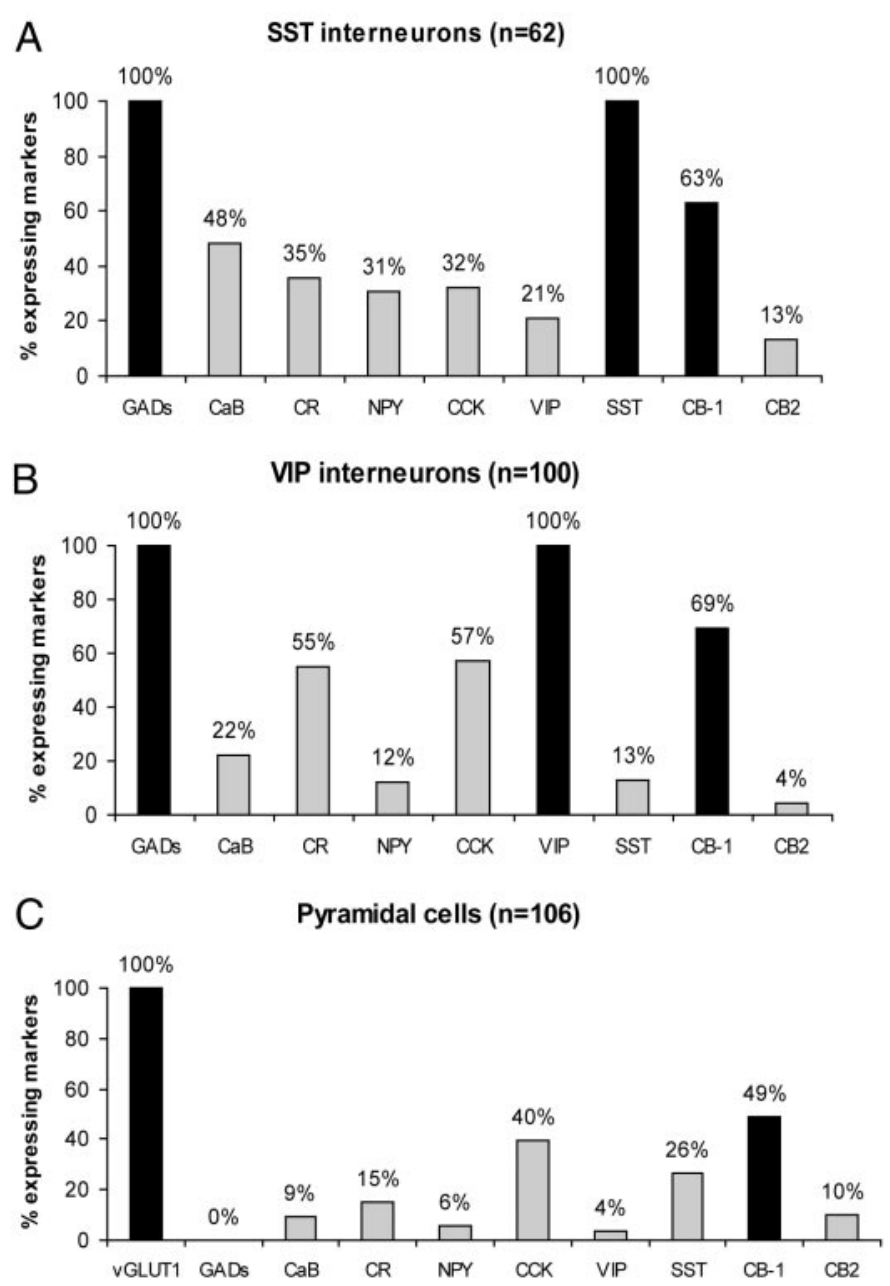

FIG. 2. Summary of scPCR. CB1 expression was probed in a total of 255 neocortical neurons comprising 62 SST-expressing interneurons, 100 VIPexpressing interneurons, and 106 pyramidal neurons. A: CB1 mRNAs were detected in $63 \%$ of SST-expressing interneurons that showed limited coexpression of VIP $(21 \%)$ or CCK $(32 \%)$. B: large proportion of VIP interneurons expressed CB1 $(69 \%)$ as well as CCK $(57 \%)$, whereas SST expression $(13 \%)$ was low in these neurons. $C$ : pyramidal neurons expressed vGlut1 but not GAD. They showed a high occurrence of CB1 mRNA (49\%), followed by CCK and SST (40 and 26\%, respectively). Note that 13 interneurons expressed both VIP and SST and were therefore included in both $A$ and $B$.

Kubota et al. 1994; Papadopoulos et al. 1987; ToledoRodriguez et al. 2005), this neuronal population frequently expressed CCK (57\%) and CR (55\%). In contrast, VIP interneurons showed low expression of SST (13\%). Analysis of pyramidal neurons revealed that $49 \%$ of these cells expressed CB1 $(n=106$, Fig. $2 C)$, with similar proportions in layer II/III $(51 \%, n=20$ of 39$)$ and in layer V $(48 \%, n=36$ of 67$)$. Only $10 \%$ of pyramidal neurons of either layers expressed CB2. As previously reported (Gallopin et al. 2006; Ong et al. 1994; Schiffmann and Vanderhaeghen 1991), pyramidal cells also expressed CCK (40\%) and to a lesser extent SST (26\%).

Consistent with its low abundance in the cortex (Van Sickle et al. 2005), the CB2 mRNA was rarely found in our sample of neocortical neurons. The expression of CB1 mRNA was only weakly correlated to that of CCK in our sample of 255 neurons (correlation coefficient: 0.19, Spearman rank correlation test, $P \leq 0.05)$. Indeed, a large percentage of cells positive for CB1 were negative for CCK in each neuronal population $(62,38$, and $44 \%$ for SST, VIP, and pyramidal cells, respectively). Hence the expression of the CB1 mRNA is broader than suggested by immunocytochemistry (Bodor et al. 2005; Katona et al. 1999; Tsou et al. 1999) but consistent with in situ hybridization studies (Marsicano and Lutz 1999) and the conditional CB1 knock-out results (Domenici et al. 2006; Marsicano et al. 2003). Specifically, CB1 receptor mRNA expression extended to SST and VIP interneurons that can be activated by cholinergic agonists as well as to glutamatergic pyramidal neurons. We next tested whether functional CB1 receptors are translated from the mRNAs expressed in SST, VIP, and pyramidal neurons.

\section{Cannabinoid actions on cholinergic responsive interneurons}

Cholinergic agonists increase the frequency and amplitude of IPSCs in the neocortex (Blatow et al. 2003; Kawaguchi 1997; Xiang et al. 1998). These IPSCs are TTX sensitive (Xiang et al. 1998) and thus stem from SST and VIP interneurons that selectively show action potential firing on cholinergic stimulation (Gulledge et al. 2006; Kawaguchi 1997; Porter et al. 1999). Because we found that the majority of SST and VIP interneurons express CB1, we assessed the effect of CB1 agonists on cholinergic-responsive interneurons by applying 3 $\mu \mathrm{M}$ of the cholinergic agonist carbamylcholine (carbachol, $\mathrm{CCh}$ ) and recording IPSCs in pyramidal neurons in the presence of glutamate receptor antagonists $(10 \mu \mathrm{M}$ CNQX and 20 $\mu \mathrm{M}$ D-APV). We used two approaches to investigate CB1 modulation of synaptic transmission in these cell populations: we first delivered a DSI paradigm (see METHODS) to establish the participation of endocannabinoids, and second we applied the synthetic CB1 agonist WIN-2.

Application of CCh consistently elicited a tonic increase in IPSC frequency (interevent interval decreased from $312.9 \pm$ 57.7 to $136.1 \pm 30.4 \mathrm{~ms} ; P<0.05$, Student's paired $t$-test) but insignificantly increased IPSC amplitude (from $18.1 \pm 1.0$ to $23.5 \pm 2.9 \mathrm{pA} ; P=0.091$, Student's paired $t$-test) in eight of eight pyramidal cells tested, including six layer II/III neurons and two layer V neurons. In the continuous presence of $\mathrm{CCh}$, delivery of DSI paradigms largely decreased the inhibitory activity recorded in four layer II/III pyramidal neurons tested (Fig. 3A). In these four pyramidal cells, CCh-elicited IPSC amplitude was reduced by $21 \pm 4 \%$ on delivery of the DSI paradigm, suggesting that $\mathrm{CB} 1$ are present on $\mathrm{CCh}$ responsive cells and are physiologically activated by endocannabinoids. No DSI was observed in the remaining four cells. We further tested the presence of $\mathrm{CB} 1$ on cholinergic responsive neurons in the same neuronal sample $(n=8)$ by applying WIN-2 $(2$ $\mu \mathrm{M}$ ), which greatly reduced the CCh-evoked IPSCs (Fig. 3B). In seven of eight cells WIN-2 reduced the IPSC amplitude by $27 \pm 8 \%$ (from $23.6 \pm 2.5$ to $16.0 \pm 1.1 \mathrm{pA}, P<0.05$, Student's paired $t$-test) and increased the interevent interval by $54 \pm 14 \%$ (from $120.7 \pm 13.4$ to $191.5 \pm 31.1 \mathrm{~ms}, P<0.05$, Student's paired $t$-test; Fig. $3 C$ ). In the remaining cell, from layer $\mathrm{V}$, we observed no effect of the DSI paradigm and of WIN-2 application on IPSCs. The effect of WIN-2 was strongly reduced by the CB1 antagonist AM 251. Indeed, in slices pretreated with $2 \mu \mathrm{M}$ AM 251, WIN-2 decreased the amplitude of CCh-evoked IPSCs by $8 \pm 1 \%$ (from $21.7 \pm 1.7$ to $20.0 \pm 1.2 \mathrm{pA} ; P<0.05$, Student's paired $t$-test) and increased the interevent Interval by $11 \pm 5 \%$ (from $123 \pm 7$ to 
A

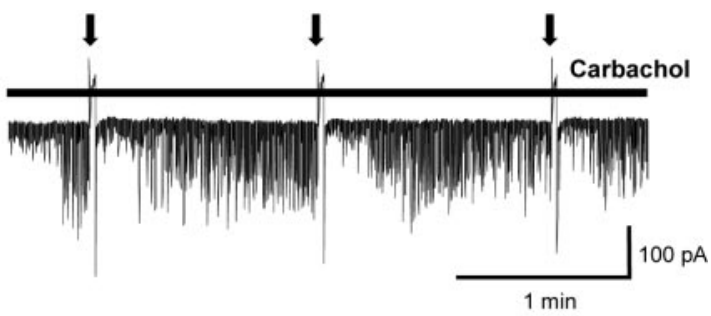

B

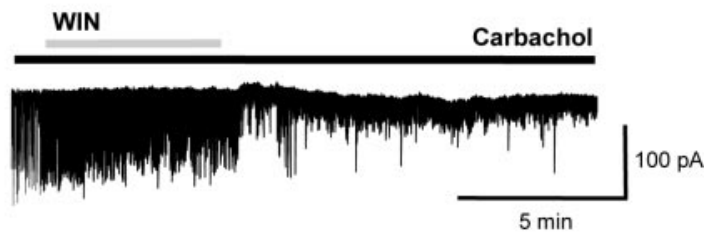

C
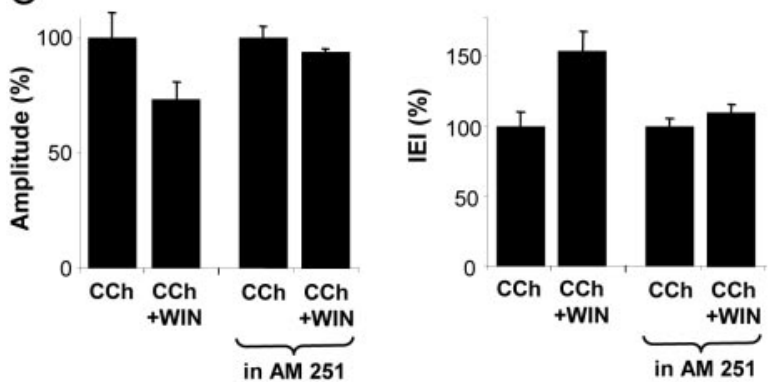

FIG. 3. Cannabinoids decrease carbachol $(\mathrm{CCh})$-elicited inhibitory postsynaptic currents (IPSCs) in pyramidal cells. A: application of $3 \mu \mathrm{M}$ CCh largely increased inhibitory synaptic activity. Delivery of depolarization-induced suppression of inhibition (DSI) paradigms (denoted by arrows) transiently depressed the CCh-elicited IPSCs (mean amplitude reduction of $42 \%$ for the 3 DSI trials). $B$ : in the same neuron, application of the CB1 agonist WIN55212-2 (WIN-2; $2 \mu \mathrm{M}$ ) decreased the amplitude of CCh-elicited IPSCs by $66 \%$. $C$ : on average, WIN-2 decreased the amplitude of CCh-elicited IPSCs by $27 \%$ and increased the interevent interval by $54 \%(n=7)$. In the continuous presence of the CB1 antagonist AM $251(2 \mu \mathrm{M})$, WIN-2 decreased the amplitude of CCh-elicited IPSCs by $8 \%$ and increased the interevent interval by $11 \%(n=5)$.

$136 \pm 11 \mathrm{~ms}, P=0.11$, Student's paired $t$-test $)(n=5$ layer II/III pyramidal cells, Fig. 3C). The pronounced effect of WIN-2 on CCh-evoked IPSCs suggests that functional CB1 and cholinergic receptors are co-expressed in SST and VIP interneurons.

Because CCh activates both muscarinic and nicotinic subtypes of cholinergic receptors, we also assessed cannabinoid effects on increased inhibitory activity elicited by the selective nicotinic agonist DMPP. In the neocortex, nicotinic receptors are principally located on VIP interneurons (Gulledge et al. 2006; Porter et al. 1999), a cell population that we found to express CB1. To minimize desensitization of the nicotinic response, we made two short (10 s) bath applications of 100 $\mu \mathrm{M}$ DMPP separated by $\geq 5 \mathrm{~min}$ in two neuronal samples. In the control sample ( $n=6$ layer II/III pyramidal neurons), the second DMPP application was performed in the absence of WIN-2, whereas in the drug sample $(n=9$ layer II/III pyramidal neurons), the second DMPP application was performed in the presence of WIN-2. The first application of DMPP largely increased IPSC amplitude (Fig. 4A). In the control sample, the response elicited by the second DMPP application was insignificantly decreased by $7 \pm 5 \%$ (from $52 \pm 1$ to $48 \pm$ $1 \mathrm{pA}, P=0.051$, Student's paired $t$-test) when compared with the first DMPP application (Fig. 4B). In the presence of $2 \mu \mathrm{M}$ WIN-2, however, the response elicited by the second DMPP application was significantly reduced by $41 \pm 5 \%$ from $49.0 \pm$ 2.1 to $28.7 \pm 0.6 \mathrm{pA}(P<0.0001$, Student's paired $t$-test; see Fig. 4, $A$ and $B$ ). This effect of WIN-2 was strongly reduced by the CB1 antagonist AM 251. In slices pretreated with $2 \mu \mathrm{M}$ AM 251, the response to the second DMPP application in the presence of $2 \mu \mathrm{M}$ WIN-2 was only decreased by $9 \pm 1 \%$ from $29.2 \pm 3.3$ to $26.5 \pm 2.9 \mathrm{pA}(n=3$ layer II/III pyramidal neurons, $P<0.05$, Student's paired $t$-test; see Fig. $4 B$ ). The marked reduction of DMPP-evoked IPSC in the presence of WIN-2 confirms that CB1 is co-expressed with nicotinic receptors on VIP interneurons.

\section{Cannabinoid actions on glutamatergic transmission}

We examined the presence of functional $\mathrm{CB} 1$ on glutamatergic neurons by stimulating intracortical excitatory connections and recording EPSCs in layer II/III pyramidal neurons. The amplitude of stimulation-evoked EPSCs was greatly reduced in the presence of WIN-2 (Fig. 5). In nine cells tested, WIN-2 significantly decreased the EPSC mean amplitude by $38 \pm 7 \%$, from $111 \pm 3$ to $69 \pm 3 \mathrm{pA}(P \ll 0.0001$, Student's paired $t$-test). At the end of the experiment, application of the nonselective glutamate receptor antagonist kynurenate sharply
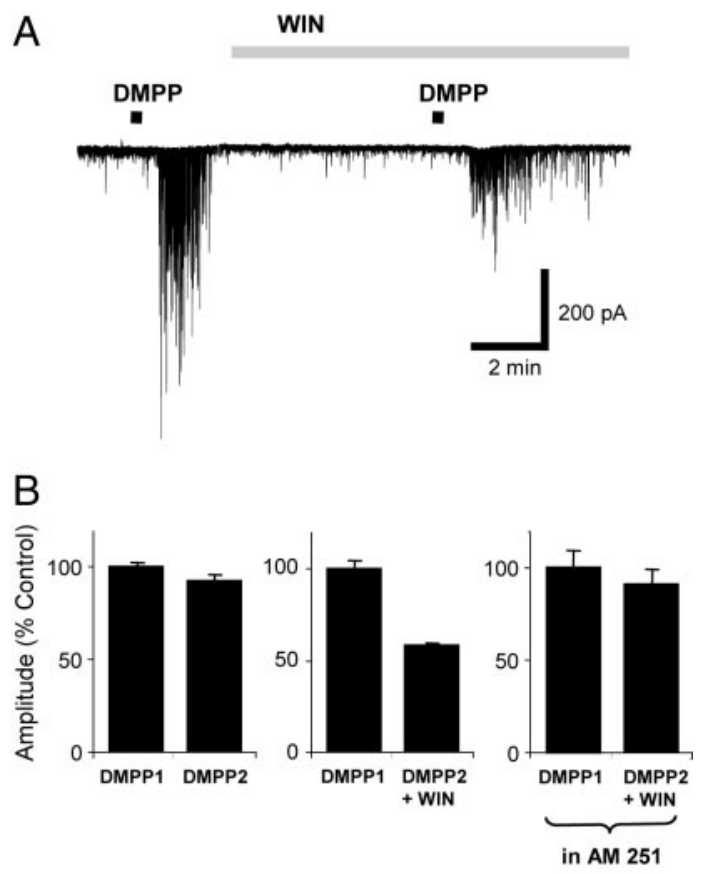

FIG. 4. WIN-2 decreases 1-1-dimethyl-4-phenyl-piperazinium iodide (DMPP)-elicited IPSCs in pyramidal cells. A: short application $(10 \mathrm{~s})$ of the selective nicotinic receptor agonist DMPP dramatically increased IPSCs. In the presence of $2 \mu \mathrm{M}$ WIN-2, a 2nd application of DMPP was less effective to raise inhibitory activity (49\% reduction of mean IPSC amplitude in this neuron). B, left: 2nd DMPP application (DMPP2) raised inhibitory activity to 93\% $(n=6)$ of the level reached with the 1st application (DMPP1). Middle: in presence of $2 \mu \mathrm{M}$ WIN-2, the 2nd DMPP application (DMPP2 in WIN) only raised inhibitory activity to $59 \%(n=9)$ of the level obtained in absence of WIN-2 (DMPP1), indicating a depression of DMPP-elicited inhibitory activity by the CB1 agonist. Right: in slices pretreated with the CB1 antagonist AM $251(2 \mu \mathrm{M})$, the 2nd DMPP application in presence of WIN-2 (DMPP2 in WIN) raised inhibitory activity to $91 \%(n=3)$ of the level obtained in absence of WIN-2 (DMPP1). 

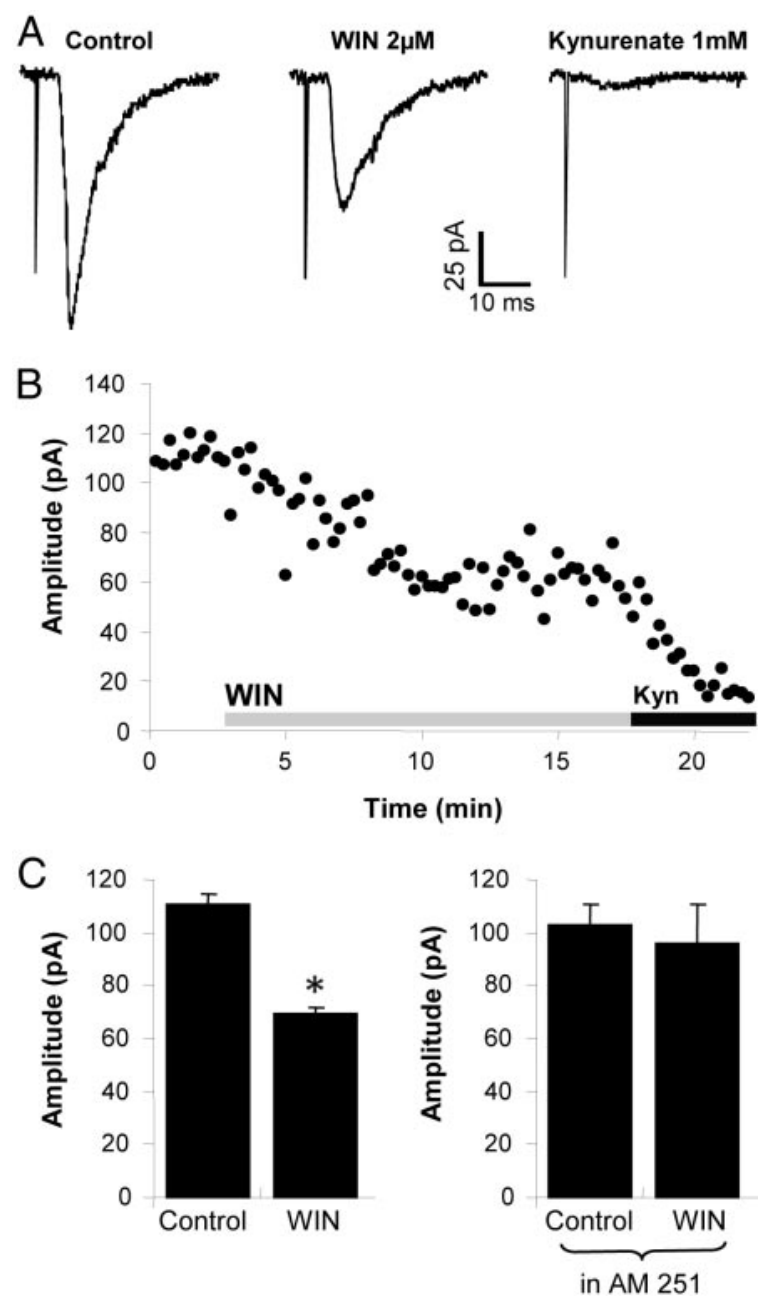

FIG. 5. Cannabinoids decrease electrically evoked glutamatergic transmission. A: excitatory postsynaptic currents (EPSCs) were evoked by stimulating locally with an electrode placed in layer II/III $\sim 250 \mu \mathrm{m}$ rostral to the recorded pyramidal neuron. Application of $2 \mu \mathrm{M}$ WIN-2 gradually decreased the EPSC amplitude. Kynurenate was subsequently applied to confirm the glutamatergic nature of the recorded response. $B$ : time course of the WIN-2 effect on EPSC amplitude (same neuron as in $A$ ). $C$ : on average, WIN-2 decreased EPSC amplitudes by $38 \%$ in pyramidal neurons $(n=9)$. In slices pretreated with the CB1 antagonist AM $251(2 \mu \mathrm{M})$, WIN-2 only decreased EPSC amplitudes by $7 \%(n=4) . *, P<0.0001$

decreased the EPSC amplitude to $16 \pm 3 \%$ of control value, confirming that the recorded postsynaptic current was essentially glutamatergic. The effect of WIN-2 was strongly reduced by the CB1 antagonist AM 251. In slices pretreated with $2 \mu \mathrm{M}$ AM 251, WIN-2 insignificantly decreased the EPSC mean amplitude by $7 \pm 7 \%$, from $102 \pm 8$ to $96 \pm 14 \mathrm{pA}(n=4$ layer II/III pyramidal cells, $P=0.44$, Student's paired $t$-test). These results suggest that a functional CB1 is expressed in neocortical pyramidal neurons and is responsible for the WIN-2 effect on excitatory transmission.

\section{I S C US S I O N}

In the present study, we have investigated the expression of $\mathrm{CB} 1$ and its role to modulate GABAergic and glutamatergic transmission in the neocortex. We found that the CB1 mRNA was frequently expressed in pyramidal neurons as well as in SST and VIP interneurons. Consistent with CB1 expression in these cholinergic-responsive interneuron populations, IPSCs elicited by cholinergic agonists were depressed by the CB1 agonist WIN-2. Also in accord with CB1 expression in pyramidal neurons, WIN-2 depressed EPSCs evoked by intracortical stimulation. WIN-2 effects were strongly reduced by the CB1 antagonist AM 251. Our results indicate a broad functional expression of $\mathrm{CB} 1$ in both GABAergic and glutamatergic neurons of the neocortex.

\section{Expression of CB1 in pyramidal neurons and multiple interneuron populations}

We found that a substantial proportion of pyramidal neurons, SST interneurons and VIP interneurons express the CB1 mRNA. These neurons were clearly distinct from the large CCK interneurons that reportedly express high levels of CB1 (Katona et al. 1999; Marsicano and Lutz 1999; Tsou et al. 1999). Indeed, the peptides VIP and SST are typically absent from large CCK interneurons (Kubota and Kawaguchi 1997; Somogyi 1984), and high-CB1-expressing large CCK interneurons present electrophysiological hallmarks such as irregular spiking discharge (Galarreta et al. 2004) or occurrence of a low-threshold calcium spike (Bacci et al. 2004) that were rarely encountered in the presently studied neurons. Previous in situ hybridization studies have shown that multiple neuronal populations may express the CB1 mRNA in the neocortex, including principal neurons, albeit at lower levels than large CCK interneurons (Marsicano and Lutz 1999; Matsuda et al. 1993). Our present scPCR results demonstrate that pyramidal neurons from layers II/III and V, SST interneurons, and VIP interneurons indeed express the CB1 mRNA. The occurrence of the CB1 mRNA in these cell populations is probably underestimated by scPCR, due to its detection limit (around 25 molecules of mRNA) and because only part of the cellular mRNA is harvested in the patch pipette (Tsuzuki et al. 2001). This is exemplified in other studies where the expression of various G-protein-coupled somatodendritic receptors was detected by scPCR in only a fraction of the neurons showing functional expression of these receptors (Ferezou et al. 2006; Gallopin et al. 2006). This suggests that the proportions of pyramidal, SST and VIP neurons expressing CB1 are larger than presently found by scPCR, consistent with the robust effects of WIN on postsynaptic currents we observed in this study.

Because of the intense binding of CB1 radioligands, the CB1 protein is believed to be one of the most abundant G-proteincoupled receptors in the brain (Herkenham et al. 1990). This intense binding, abolished in CB1 knock-out mice (Zimmer et al. 1999), is relatively uniform in the neocortex (Herkenham et al. 1990), a distribution inconsistent with immunodetection of the CB1 protein mainly in large CCK cells (Bodor et al. 2005; Katona et al. 1999; Tsou et al. 1999). A plausible explanation to this discrepancy is that bivalent binding of antibodies is much stronger than monovalent binding (Hornick and Karush 1972; Mattes 1997; Turner 2002) and, as a consequence, the affinity of antibodies sharply drops with the density of their antigens, especially for immobile antigens (Kaufman and Jain 1992) found in fixed tissues. The resulting threshold effect may only allow detection of dense CB1 expression sites under the stringent conditions used to ensure specific immuno-histochemical staining. Therefore we propose that the CB1 protein 
is present in pyramidal neurons as well as SST interneurons and VIP interneurons, albeit at lower levels than in large CCK interneurons, as suggested by their cognate CB1 mRNA expression levels (Marsicano and Lutz 1999; Matsuda et al. 1993). This is supported by the recent observation that the CB1 protein is detected in excitatory axon terminals at asymmetrical synapses in the forebrain using immuno-electron microscopy (Katona et al. 2006; Kawamura et al. 2006).

\section{CB1 effects on cholinergic responsive interneurons}

We found that CB1 activation depressed GABAergic IPSCs elicited by cholinergic agonists in pyramidal neurons. This effect was strongly reduced by the CB1 antagonist AM 251 . The different sensitivities of neocortical interneuron subtypes to cholinergic agonists have been established in previous reports. Cholinergic agonists elicit a marked excitation of SST and VIP interneurons accompanied by firing of action potentials (Gulledge et al. 2006; Kawaguchi 1997; Porter et al. 1999), whereas "fast spiking" and "late spiking" interneurons are either insensitive or inhibited by cholinergic agonists (Gulledge et al. 2006; Kawaguchi 1997; Porter et al. 1999; Xiang et al. 1998). In large CCK interneurons, cholinergic agonists elicit a sequence of hyperpolarization-depolarization that usually does not trigger the firing of action potentials (Kawaguchi 1997) or an inhibitory response (Gulledge et al. 2006). Therefore the CCh-induced IPSCs recorded in the present study originated principally from SST and VIP interneurons. Hence our results indicate that the depressing effect of WIN-2 on CCh-induced IPSCs is due to activation of CB1, consistent with the scPCR detection of CB1 mRNAs in SST and VIP interneurons.

It is now well established that DSI is mediated by a retrograde action of endogenously formed cannabinoids (Wilson and Nicoll 2001), and DSI has been described in neocortex (Bodor et al. 2005; Trettel and Levine 2003). Recent data obtained in neocortex also indicated that GABAergic interneurons depolarized by muscarinic agonists provide the majority of DSI-susceptible inputs to pyramidal neurons (Trettel et al. 2004). Our data showing that delivery of a DSI paradigm depressed CCh-induced IPSCs confirm these results and indicate that CB1 expressed by SST and VIP interneurons are physiologically activated by endogenously released cannabinoids. Whereas both SST and VIP interneurons are depolarized by muscarinic receptor agonists (Kawaguchi 1997), only VIP interneurons are depolarized by nicotinic receptor agonists (Porter et al. 1999). The observation that WIN-2 depressed IPSCs elicited by application of a nicotinic receptor agonist further confirms that functional CB1 receptors are expressed in VIP interneurons.

\section{CB1 effects on glutamatergic transmission}

Although CB1 immunoreactivity has often been undetected in pyramidal neurons of the forebrain (Bodor et al. 2005; Katona et al. 1999; Tsou et al. 1999), molecular and functional data indicate that the CB1 receptor is indeed expressed in these neurons as recently shown on hippocampal excitatory axon terminals using immuno-electron microscopy (Katona et al. 2006; Kawamura et al. 2006). The present molecular data indicate that CB1 is expressed in neocortical pyramidal neurons from both layers II/III and V. We corroborated our molecular findings by testing the effects of the CB1 agonist WIN-2 on intracortical glutamatergic inputs onto layer II/III pyramidal neurons. We found that the reduction of excitatory synaptic transmission by WIN-2 was strongly reduced by the CB1 antagonist AM 251, indicating that functional CB1 receptors are indeed present on neocortical pyramidal neurons. These results are consistent with numerous physiological reports demonstrating direct CB1 effects on intracortical glutamatergic connections originating from pyramidal neurons of both layers II/III and V (Auclair et al. 2000; Bender et al. 2006; Fortin and Levine 2006; Sjostrom et al. 2003, 2004). Therefore we propose that functional CB1 receptors are widely expressed in neocortical pyramidal neurons and account for the cannabinoid effects on excitatory transmission in this brain region.

\section{Modulation of the neocortical network by CBI}

Given the low occurrence of the CB2 mRNA observed in the present study, it is likely that CB1 mediates most of the cannabinoid effects on neocortical neurons. It is established that cannabinoids act at CB1 to hyperpolarize large CCK interneurons (Bacci et al. 2004) and to decrease their GABAergic output (Galarreta et al. 2004). The present results indicate that CB1 mediates cannabinoid effects on other cell types, including pyramidal glutamatergic neurons. In light of our data, CB1 appears to play a major role to modulate cortical activity by acting on both glutamatergic and GABAergic neurons. We therefore propose that endocannabinoids acting at CB1 modulate the synaptic output of several neuronal types to influence neocortical networks. Depolarization of pyramidal neurons triggers the production of endocannabinoids, which act as retrograde messengers to inhibit GABA release (DSI) and to elicit short- or long-term depression of glutamate release (Diana and Marty 2004; Gerdeman and Lovinger 2003). It is likely that neocortical DSI involves endocannabinoid actions on axon terminals of large CCK interneurons and of cholinergic responsive SST and VIP interneurons. Similarly, endocannabinoids acting at $\mathrm{CB} 1$ inhibit glutamate release from axon terminals of layers II/III and V pyramidal neurons in the neocortex.

\section{A C KN OWLEDGMENTS}

We thank P. Gouédard and G. Forget for assistance with the database.

\section{G R A N T S}

This work was supported by Centre National de la Recherche Scientifique and Fondation pour la Recherche Médicale. P. Schweitzer was supported by National Institutes of Drug Abuse Grant DA-13658.

\section{REFERENCES}

Auclair N, Otani S, Soubrie P, Crepel F. Cannabinoids modulate synaptic strength and plasticity at glutamatergic synapses of rat prefrontal cortex pyramidal neurons. J Neurophysiol 83: 3287-3293, 2000.

Bacci A, Huguenard JR, Prince DA. Long-lasting self-inhibition of neocortical interneurons mediated by endocannabinoids. Nature 431: 312-316, 2004.

Bayraktar T, Welker E, Freund TF, Zilles K, Staiger JF. Neurons immunoreactive for vasoactive intestinal polypeptide in the rat primary somatosensory cortex: morphology and spatial relationship to barrel-related columns. J Comp Neurol 420: 291-304, 2000. 
Bender VA, Bender KJ, Brasier DJ, Feldman DE. Two coincidence detectors for spike timing-dependent plasticity in somatosensory cortex. $\mathrm{J} \mathrm{Neu-}$ rosci 26: 4166-4177, 2006.

Blatow M, Rozov A, Katona I, Hormuzdi SG, Meyer AH, Whittington MA, Caputi A, Monyer H. A novel network of multipolar bursting interneurons generates theta frequency oscillations in neocortex. Neuron 38 : $805-817,2003$.

Bochet P, Audinat E, Lambolez B, Crepel F, Rossier J, Iino M, Tsuzuki K, Ozawa S. Subunit composition at the single-cell level explains functional properties of a glutamate-gated channel. Neuron 12: 383-388, 1994.

Bodor AL, Katona I, Nyiri G, Mackie K, Ledent C, Hajos N, Freund TF. Endocannabinoid signaling in rat somatosensory cortex: laminar differences and involvement of specific interneuron types. $J$ Neurosci 25: 6845-6856, 2005.

Cauli B, Audinat E, Lambolez B, Angulo MC, Ropert N, Tsuzuki K, Hestrin S, Rossier J. Molecular and physiological diversity of cortical nonpyramidal cells. J Neurosci 17: 3894-3906, 1997.

Cauli B, Porter JT, Tsuzuki K, Lambolez B, Rossier J, Quenet B, Audinat E. Classification of fusiform neocortical interneurons based on unsupervised clustering. Proc Natl Acad Sci USA 97: 6144-6149, 2000.

Davies SN, Pertwee RG, Riedel G. Functions of cannabinoid receptors in the hippocampus. Neuropharmacology 42: 993-1007, 2002.

Diana MA, Marty A. Endocannabinoid-mediated short-term synaptic plasticity: depolarization-induced suppression of inhibition (DSI) and depolarization-induced suppression of excitation (DSE). Br J Pharmacol 142: 9-19, 2004.

Domenici MR, Azad SC, Marsicano G, Schierloh A, Wotjak CT, Dodt HU, Zieglgansberger W, Lutz B, Rammes G. Cannabinoid receptor type 1 located on presynaptic terminals of principal neurons in the forebrain controls glutamatergic synaptic transmission. J Neurosci 26: 5794-5799, 2006.

Ferezou I, Cauli B, Hill EL, Rossier J, Hamel E, Lambolez B. 5-HT3 receptors mediate serotonergic fast synaptic excitation of neocortical vasoactive intestinal peptide/cholecystokinin interneurons. J Neurosci 22: 73897397, 2002.

Ferezou I, Hill EL, Cauli B, Gibelin N, Kaneko T, Rossier J, Lambolez B. Extensive overlap of Mu-Opioid and nicotinic sensitivity in cortical interneurons. Cereb Cortex 10.1093/cercor/bhl104, 2006.

Fortin DA, Levine ES. Differential effects of endocannabinoids on glutamatergic and GABAergic inputs to layer 5 pyramidal neurons. Cereb Cortex 10.1093/cercor/bhj133, 2006

Freund TF, Katona I, Piomelli D. Role of endogenous cannabinoids in synaptic signaling. Physiol Rev 83: 1017-1066, 2003.

Galarreta M, Erdelyi F, Szabó, B, Hestrin S. Electrical coupling among irregular-spiking GABAergic interneurons expressing cannabinoid receptors. J Neurosci 24: 9770-9778, 2004.

Gallopin T, Geoffroy H, Rossier J, Lambolez B. Cortical sources of CRF, $\mathrm{NKB}$, and CCK and their effects on pyramidal cells in the neocortex. Cereb Cortex 16: 1440-1452, 2006.

Gerdeman GL, Lovinger DM. Emerging roles for endocannabinoids in long-term synaptic plasticity. Br J Pharmacol 140: 781-789, 2003.

Gonchar Y, Burkhalter A. Three distinct families of GABAergic neurons in rat visual cortex. Cereb Cortex 7: 347-358, 1997.

Gulledge AT, Park SB, Kawaguchi Y, Stuart G. Heterogeneity of phasic cholinergic signalling in neocortical neurons. J Neurophysiol 97: 22152229, 2007.

Herkenham M, Lynn AB, Little MD, Johnson MR, Melvin LS, De Costa BR, Rice KC. Cannabinoid receptor localization in brain. Proc Natl Acad Sci USA 87: 1932-1936, 1990.

Hornick CL, Karush F. Antibody affinity. III. The role of multivalence. Immunochemistry 9: 325-340, 1972

Iversen L. Cannabis and the brain. Brain 126: 1252-1270, 2003.

Katona I, Sperlágh B, Sík A, Käfalvi A, Vizi ES, Mackie K, Freund TF. Presynaptically located CB1 cannabinoid receptors regulate GABA release from axon terminals of specific hippocampal interneurons. J Neurosci 19: 4544-4558, 1999.

Katona I, Urban GM, Wallace M, Ledent C, Jung KM, Piomelli D, Mackie K, Freund TF. Molecular composition of the endocannabinoid system at glutamatergic synapses. J Neurosci 26: 5628-5637, 2006.

Kaufman EN, Jain RK. Effect of bivalent interaction upon apparent antibody affinity: experimental confirmation of theory using fluorescence photobleaching and implications for antibody binding assays. Cancer Res 52: 4157-4167, 1992.
Kawaguchi Y. Groupings of nonpyramidal and pyramidal cells with specific physiological and morphological characteristics in rat frontal cortex. $\mathrm{J} \mathrm{Neu}$ rophysiol 69: 416-431, 1993.

Kawaguchi Y. Physiological subgroups of nonpyramidal cells with specific morphological characteristics in layer II/III of rat frontal cortex. $J$ Neurosci 15: 2638-2655, 1995 .

Kawaguchi Y. Selective cholinergic modulation of cortical GABAergic cell subtypes. J Neurophysiol 78: 1743-1747, 1997.

Kawaguchi Y, Kubota Y. Correlation of physiological subgroupings of nonpyramidal cells with parvalbumin- and calbindinD28k-immunoreactive neurons in layer V of rat frontal cortex. J Neurophysiol 70: 387-396, 1993.

Kawaguchi Y, Kubota Y. Physiological and morphological identification of somatostatin- or vasoactive intestinal polypeptide-containing cells among GABAergic cell subtypes in rat frontal cortex. $J$ Neurosci 16: 2701-2715, 1996.

Kawamura Y, Fukaya M, Maejima T, Yoshida T, Miura E, Watanabe M, Ohno-Shosaku T, Kano M. The CB1 cannabinoid receptor is the major cannabinoid receptor at excitatory presynaptic sites in the hippocampus and cerebellum. J Neurosci 26: 2991-3001, 2006

Kubota Y, Hattori R, Yui Y. Three distinct subpopulations of GABAergic neurons in rat frontal agranular cortex. Brain Res 649: 159-173, 1994.

Kubota Y, Kawaguchi Y. Two distinct subgroups of cholecystokinin-immunoreactive cortical interneurons. Brain Res 752: 175-183, 1997.

Lambolez B, Audinat E, Bochet P, Crepel F, Rossier J. AMPA receptor subunits expressed by single Purkinje cells. Neuron 9: 247-258, 1992.

Marsicano G, Lutz B. Expression of the cannabinoid receptor CB1 in distinct neuronal subpopulations in the adult mouse forebrain. Eur J Neurosci 11: 4213-4225, 1999.

Marsicano G, Goodenough S, Monory K, Hermann H, Eder M, Cannich A, Azad SC, Cascio MG, Gutiérrez SO, Van der Stelt M, LópezRodríguez ML, Casanova E, Schütz G, Zieglgänsberger W, Di Marzo V, Behl C, Lutz B. CB1 cannabinoid receptors and on-demand defense against excitotoxicity. Science 302: 84-88, 2003.

Martin LA, Alger BE. Muscarinic facilitation of the occurrence of depolarization-induced suppression of inhibition in rat hippocampus. Neuroscience 92: 61-71, 1999.

Matsuda LA, Bonner TI, Lolait SJ. Localization of cannabinoid receptor mRNA in rat brain. J Comp Neurol 327: 535-550, 1993.

Mattes MJ. Binding parameters of antibodies reacting with multivalent antigens: functional affinity or pseudo-affinity. J Immunol Methods 202: 97-101, 1997.

Ong WY, Garey LJ, Sumi Y. Distribution of preprosomatostatin mRNA in the rat parietal and temporal cortex. Brain Res Mol Brain Res 23: 151-156, 1994.

Papadopoulos GC, Parnavelas JG, Cavanagh ME. Extensive co-existence of neuropeptides in the rat visual cortex. Brain Res 420: 95-99, 1987.

Piomelli D. The molecular logic of endocannabinoid signaling. Nat Rev Neurosci 4: 873-884, 2003.

Porter JT, Cauli B, Staiger JF, Lambolez B, Rossier J, Audinat E. Properties of bipolar VIPergic interneurons and their excitation by pyramidal neurons in the rat neocortex. Eur J Neurosci 10: 3617-3628, 1998.

Porter JT, Cauli B, Tsuzuki K, Lambolez B, Rossier J, Audinat E. Selective excitation of subtypes of neocortical interneurons by nicotinic receptors. J Neurosci 19: 5228-5235, 1999.

Schiffmann SN, Vanderhaeghen JJ. Distribution of cells containing mRNA encoding cholecystokinin in the rat central nervous system. J Comp Neurol 304: 219-233, 1991.

Sjostrom PJ, Turrigiano GG, Nelson SB. Neocortical LTD via coincident activation of presynaptic NMDA and cannabinoid receptors. Neuron 39: 641-654, 2003

Sjostrom PJ, Turrigiano GG, Nelson SB. Endocannabinoid-dependent neocortical layer-5 LTD in the absence of postsynaptic spiking. J Neurophysiol 92: 3338-3343, 2004.

Skaper SD, Buriani A, Dal Toso R, Petrelli L, Romanello S, Facci L, Leon A. The ALIAmide palmitoylethanolamide and cannabinoids, but not anandamide, are protective in a delayed postglutamate paradigm of excitotoxic death in cerebellar granule neurons. Proc Natl Acad Sci USA. 93: 3984 39989, 1996.

Somogyi P, Hodgson AJ, Smith AD, Nunzi MG, Gorio A, Wu JY. Different populations of GABAergic neurons in the visual cortex and hippocampus of cat contain somatostatin- or cholecystokinin-immunoreactive material. J Neurosci 4: 2590-2603, 1984. 
Stuart GJ, Dodt HU, Sakmann B. Patch-clamp recordings from the soma and dendrites of neurons in brain slices using infrared video microscopy. Pfluegers 423: 511-518, 1993.

Takahashi KA, Castillo PE. The CB1 cannabinoid receptor mediates glutamatergic synaptic suppression in the hippocampus. Neuroscience 139: 795-802, 2006

Toledo-Rodriguez M, Goodman P, Illic M, Wu C, Markram H. Neuropeptide and calcium binding protein gene expression profiles predict neuronal anatomical type in the juvenile rat. $J$ Physiol 567: 401-413, 2005.

Trettel J, Fortin DA, Levine ES. Endocannabinoid signaling selectively targets perisomatic inhibitory inputs to pyramidal neurons in juvenile mouse neocortex. J Physiol 556: 95-107, 2004.

Trettel J, Levine ES. Cannabinoids depress inhibitory synaptic inputs received by layer $2 / 3$ pyramidal neurons of the neocortex. J Neurophysiol 88: 534-539, 2002.

Trettel J, Levine ES. Endocannabinoids mediate rapid retrograde signaling at interneuron 224 pyramidal neuron synapses of the neocortex. J Neurophysiol 89: 2334-2338, 2003.

Tsou K, Mackie K, Sañudo-Peña MC, Walker JM. Cannabinoid CB1 receptors are localized primarily on cholecystokinin-containing gabaergic interneurons in the rat hippocampal formation. Neuroscience 93: 969-975, 1999.
Tsuzuki K, Lambolez B, Rossier J, Ozawa S. Absolute quantification of AMPA receptor subunit mRNAs in single hippocampal neurons. J Neurochem 77: 1650-1659, 2001.

Turner M. Antibodies. In: Immunology (6th ed.), edited by Roitt IM, Brostoff J, Male DK. London: Mosby, 2002, chapt. 4, p. 71-74.

Van Sickle MD, Duncan M, Kingsley PJ, Mouihate A, Urbani P, Mackie K, Stella N, Makriyannis A, Piomelli D, Davison JS, Marnett LJ, Di Marzo V, Pittman QJ, Patel KD, Sharkey KA. Identification and functional characterization of brainstem cannabinoid CB2 receptors. Science 310: 329-332, 2005.

Wang Y, Toledo-Rodriguez M, Gupta A, Wu C, Silberberg G, Luo J, Markram H. Anatomical, physiological and molecular properties of Martinotti cells in the somatosensory cortex of the juvenile rat. J Physiol 561: 65-90, 2004.

Wilson RI, Nicoll RA. Endogenous cannabinoids mediate retrograde signalling at hippocampal synapses. Nature 410: 588-592, 2001.

Xiang Z, Huguenard JR, Prince DA. Cholinergic switching within neocortical inhibitory networks. Science 281: 985-988, 1998.

Zimmer A, Zimmer AM, Hohmann AG, Herkenham M, Bonner TI. Increased mortality, hypoactivity, and hypoalgesia in cannabinoid CB1 receptor knockout mice. Proc Natl Acad Sci USA 96: 5780-5785, 1999. 